\title{
"PERVERSITY, FUTILITY, JEOPARDY": AN ECONOMIC ANALYSIS OF THE ATTACK ON GUN CONTROL
}

\author{
PHILIP J. COOK* AND JAMES A. LEITZEL**
}

\section{INTRODUCTION}

In his 1991 book The Rhetoric of Reaction, Albert O. Hirschman identified three arguments that are commonly mustered against proposed "progressive" reforms. ${ }^{1}$ One argument contends that the proposed reform will have results exactly the opposite of those intended by the reform's proponents; the second is that the reform will have no effect at all; and the third is that the reform will come at the cost of degrading fundamental rights or values-freedom itself, for instance. ${ }^{2}$ The labels for these three arguments form the subtitle of Hirschman's book: "Perversity, Futility, Jeopardy."

Gun control has long been a contentious issue in the United States. A wide spectrum of laws regulating the manufacture, import, sale, possession, and use of guns, with the ultimate purpose of reducing gun violence, can be deemed "gun control laws." Such laws have attracted a good deal of opposition. Given his argument, Hirschman should be pleased to learn that the "rhetoric of reaction" has indeed been brought to bear on the issue of gun control:

Gun-control laws don't work. What is worse, they act perversely. While legitimate users of firearms encounter intense regulation, scrutiny, and bureaucratic control, illicit markets easily adapt to whatever difficulties a free society throws in their way. Also, efforts to curtail the supply of firearms inflict collateral damage on freedom and privacy interests that have long been considered central to American public life. Thanks to the seemingly never-ending war on drugs and long experience attempting to suppress prostitution and pornography, we know a great deal about how illicit markets function and how costly to the public attempts to control them can be. ${ }^{4}$

Anti-gun-control advocates frequently complement perversity, futility, or jeopardy claims with a proposed alternative to gun control: namely, severe

Copyright $\odot 1996$ by Law and Contemporary Problems

* Terry Sanford Distinguished Professor of Public Policy Studies, Sanford Institute of Public Policy, Duke University.

** Associate Professor of Public Policy Studies, Sanford Institute of Public Policy, Duke University. (1991)

1. AlbERT O. HIRSCHMAN, THE RHETORIC OF REACTION: PERVERSITY, FUTILITY, JEOPARDY

2. Id. at 7 .

3. See id. at 7-8 (explaining that these arguments are not exclusive, but they "are most typical of conservative attacks on existing or proposed progressive policies").

4. Daniel P. Polsby, The False Promise of Gun Control, ATlANTIC MONTHLY, Mar. 1994, at 57, 58. Polsby goes on to present a "futility theorem" that attempts to explain why gun controls will either fail or have perverse consequences. Id. at 60 . 
punishment for those who misuse guns. ${ }^{5}$ The proponents of this alternative suggest that in addition to their other shortcomings, gun controls are unnecessary or superfluous.

The rhetoric that is arrayed against gun controls is formidable but does not stand up to dispassionate analysis. Purveyors of the perversity or futility arguments tend to rely, implicitly or explicitly, on the following syllogism: Gun regulations apply only to the formal gun market; criminals get their guns through informal channels; therefore, regulations cannot influence the availability of guns to criminals. ${ }^{6}$ This logic, however, is faulty; the conclusion does not follow from the premises. Even regulations that do not apply to the informal market may nevertheless influence the informal market, and hence alter the availability of guns to criminals. Furthermore, the first premise is flawed. Some steps can be taken to disrupt the informal market directly.

Our purpose in this article is to bring to bear standard economic reasoning, in particular the economics of informal markets, to examine the potential for firearm-regulatory policy to mitigate the violent-crime problem. The article's primary focus is on regulations intended to reduce availability of guns to dangerous people. Our analysis suggests that this preemptive approach to gun violence cannot be dismissed out of hand by perversity or futility claims; indeed, some preemptive measures are likely to form part of a sensible public policy toward firearms.

The remainder of the article is organized as follows. Part II sets the stage by describing existing U.S. gun regulations, including restrictions on transactions, possession, and use, at the federal, state, and local levels. Part III presents a discussion of the economic rationale for preemptive gun controls. Parts IV and $\mathrm{V}$ examine the consequences of regulating the formal market, while Part VI discusses the potential to influence directly the informal market for firearms. Together, Parts IV, V, and VI indicate the conditions under which gun controls are likely to be futile, or lead to perverse outcomes. Part VII examines important collateral interests that might be jeopardized by firearm regulations, and Part VIII presents conclusions.

\section{II}

\section{Gun Laws, Gun MaRkets, AND ExISTING Gun REgulations}

Commerce in guns and the possession and use of guns are regulated by federal, state, and local governments. The complexity of this scheme results from the underlying objective of establishing a moderate "middle ground" between laissez faire and prohibition, preserving legitimate uses of guns while

5. See, e.g., Wayne R. LAPIERRE, GunS, CRIME, AND FReEdom 111-28 (1994).

6. For example, "[s]ince felons rarely obtain guns through retail channels, controls imposed at the point of retail sale necessarily miss the vast majority of criminal firearms transactions. It is thus an easy prediction that the national five-day waiting period will have no effect on the acquisition of guns by criminals because that is not how the bad guys get their guns in the first place." James D. Wright, Ten Essential Observations on Guns in America, SOC'Y, Mar.-Apr. 1995, at 66. 
preempting their use as an instrument in criminal violence. ' Gun controls discriminate among types of weapons, categories of people, and uses: A drugaddicted felon using a machine gun to shoot squirrels in Central Park is on the wrong side of a number of laws, while a farmer using a .22 rifle to shoot woodchucks on her property is mostly beyond legal reproach.

A primary purpose of federal law is to prevent lax firearm controls in one state from undermining a more restrictive regime in another state. For example, the citizens of Montana may favor a more permissive system than those living in the more urban and crime-ridden state of New Jersey, and both can be accommodated if transfers between states are effectively regulated. To this end, the Gun Control Act of 1968 limits mail-order shipments of firearms to federally licensed dealers, who are required to obey state and local ordinances in conducting their businesses. ${ }^{8}$ Sales of handguns to out-of-state residents are prohibited. ${ }^{9}$

To facilitate criminal investigations, federal law also specifies record-keeping requirements for importers, manufacturers, and retail dealers. ${ }^{10}$ It further limits commerce by banning transactions in "weapons of mass destruction" (fully automatic firearms, sawed-off shotguns, hand grenades), while banning imports of certain types of handguns and "assault weapons," and imposing an excise tax on all manufactures and imports-ten percent for handguns, eleven percent for long guns. ${ }^{11}$

The Gun Control Act establishes a minimal set of restrictions on who may possess a gun. ${ }^{12}$ Felons, drug addicts, fugitives, and a few other categories are barred. ${ }^{13}$ The Brady Law of 1993 requires that the states institute some sort of criminal record check for those seeking to buy handguns from licensed dealers. ${ }^{14}$

While federal law provides minimum standards for firearm transfers based on characteristics of the buyers and the guns, many states have enacted additional controls. ${ }^{15}$ Furthermore, all but one state (Vermont) prohibit carrying a concealed firearm without a special permit or license. ${ }^{16}$ Localities typically impose "place and manner" restrictions that outlaw the discharge of

7. Philip J. Cook \& James Blose, State Programs for Screening Handgun Buyers, 455 ANNALS AM. ACAD. POL. \& SOC. SCI. 80 (1981); Stephen P. Teret, Policies to Prevent Firearm Injuries, 12 HEALTH AFF. 96 (Winter 1993); Franklin E. Zimring, Firearms, Violence and Public Policy, 265 SCIENTIFIC AM. 48 (1991); Franklin E. Zimring, Firearms and Federal Law: The Gun Control Act of 1968, 4 J. LEG. STUD. 133 (1975).

8. 18 U.S.C. § 922(a) (1994); see also Zimring, Firearms and Federal Law, supra, note 7, at 149.

9. 18 U.S.C. $\$ 922(\mathrm{e})(1994)$.

10. Treas. Reg. \$178.124 (1968); see also Zimring, Firearms and Federal Law, supra note 7, at 150.

11. 18 U.S.C. \& 922(h) (1994).

12. 18 App. U.S.C. $\$ 1202(a)$.

13. 18 U.S.C. $\$ 922($ a) (1994).

14. P.L. No. 103-159, 107 Stat. 1536 (1993) (codified at 18 U.S.C. $\$ 922(q)$-(t) (1994)).

15. Cook \& Blose, supra note 7 , at 84-86.

16. See generally NRA Institute for Legislative Action, Index of/gun-laws (Feb. 23, 1996) $<$ http://www.nra.org/gun-laws/> [hereinafter NRA Home Page]; id. </VT.html/> (summarizing Vermont gun control laws as of May 1995). 
a gun within city limits, for instance, or prohibit carrying a firearm on school grounds. $^{17}$

A general principle that underlies many gun regulations is to limit the misuse of guns without imposing significant burdens on legitimate uses, which include target shooting, collecting, hunting, and personal protection. ${ }^{18}$ Thus, there are prohibitions on sale to high-risk individuals such as youths, felons, and the mentally ill, ${ }^{19}$ restrictions on weapons that have little sporting purpose or are particularly lethal, ${ }^{20}$ and restrictions on concealed carrying. ${ }^{21}$ Stricter controls on handguns than on long guns are justified by handguns' vastly disproportionate use in crime and their reduced value in hunting relative to long guns. $^{22}$

Besides preemptive regulations such as those noted above, there are criminal and civil penalties for people who misuse firearms. ${ }^{23}$ In particular, some jurisdictions have sentence-enhancement laws whereby prison terms are automatically extended for crimes committed with firearms. ${ }^{24}$

\section{III}

\section{AN ECONOMIC RATIONALE FOR PREEMPTION}

Gun-control measures are intended to preempt criminal uses of guns. If the criminal justice system were entirely effective at deterring such uses, then the case for gun controls would be weakened. ${ }^{25}$ Indeed, some who oppose controls offer as one argument that guns would cease to be a problem if we stopped "coddling" criminals; with punishment sufficiently harsh and likely, violent crime rates would subside to a tolerable level. ${ }^{26}$ But what we know of gun violence

17. See, e.g., DURHAM, N.C., CODE OF ORDINANCES $\S \S 12-22$ to 12-27 (1996).

18. See Philip J. Cook, The "Saturday Night Special": An Assessment of Alternative Definitions From a Policy Perspective, 72 J. CRIM. L. \& CRIMINOLOGY 1735 (1981) (advancing the notion that the appropriate standard for gun regulations is the "relative attractiveness to violent criminals").

19. See, e.g., WASH. REV. CODE ANN. \$ 9.41.080 (West 1988; Supp. 1994)(referencing \$ 9.41.040).

20. See, e.g., id. $\$ 9.41 .250$.

21. See, e.g., id. \$\$ $9.41 .050, .070$.

22. Philip J. Cook \& Mark H. Moore, Gun Control, in CRIME 270 (James Q. Wilson et al. eds, 1995).

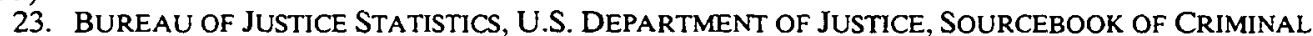
JUSTICE STATISTICS 452 (1992).

24. See, e.g., David McDowall et al., A Comparative Study of the Preventative Effects of Mandatory Sentencing Laws for Gun Crimes, 83 J. CRIM. L. \& CRIMINOLOGY 378 (1992).

25. Some would continue to advocate preemptive gun controls, even in the absence of criminal use, as a means for reducing gun suicide and accidental shootings. See Richard H. Seiden, Suicide Prevention: A Public HealthPublic Policy Approach, OMEGA 267 (1977); Daniel Webster et al., Reducing Firearm Injuries, ISSUES SCI. \& TECH., Spring 1995, at 73; Suicide in America, in MAYO Clinic Health LeTTER 1 (Sept. 1985); Garen J. Wintemute, Firearms as a Cause of Death in the United States, 1920-1982, J. TRAUMA 532 (1987); Garen J. Wintemute et al., The Epidemiology of Firearm Deaths Among Residents of California, WEST. J. MED., Mar. 1987, at 374.

26. Gun-control opponents have called for more aggressive crime-control policies. A statement prepared by the NRA claims that Crimestrike, an NRA campaign to reform the criminal justice system, "stands in support of measures America's men and women in blue support-truth-in-sentencing, mandatory sentencing, pretrial detention, treating violent juveniles as adults, eliminating posh prison conditions and the death penalty." NRA Home Page, supra note 16. 
leads to a quite different conclusion, namely that there is no reason to believe that an appropriate use of the criminal sanction would negate the need for preemptive measures in this area. The case for gun control is analogous to the case for laws requiring that only those with licenses may drive, and then only when sober and equipped with a safe vehicle. Our legal strategy for reducing wrecks on the highway does not rely solely on the threat of punishment, nor, we argue, should our legal strategy for reducing criminal assaults with guns. ${ }^{27}$

\section{A. The Limits of Ex Post Liability}

Admittedly, the most direct approach to dealing with the externalities involved in gun ownership and use would be to internalize those costs and benefits via a liability policy. Under such a system, those whose misuse of firearms results in external costs would be required to pay compensation. ${ }^{28} \mathrm{We}$ can imagine a pure liability regime in which gun production, transfer, ownership, and possession (concealed or open) would all be legal and unregulated. The misuse of a firearm-brandishing it or firing it for unprovoked intimidation or for the commission of a crime-would result in the perpetrators facing a fine equal to the value of the external cost. ${ }^{29}$ Such a liability regime would, in theory, provide the proper incentives for efficient firearm handling. ${ }^{30}$

NRA Executive Vice-President Wayne LaPierre writes,

Today juveniles are breaking laws at a record rate. The bleeding hearts have turned the juvenile justice system into a joke in order to protect "these poor misguided children who have a tough life." As a result, violent juveniles scoff at the system and at the very thought of punishment. . . The laws must be changed. Juveniles who commit violent acts with firearms need to be locked up behind bars. They aren't children; they are terrorists running rampant in our communities. One thing is absolutely certain-when they are locked up and off the streets they can't commit crimes.

LAPIERRE, supra note 5, at 77.

27. For a pioneering article with respect to ex ante regulation and ex post liability, see Donald Wittman, Prior Regulation Versus Post Liability: The Choice Between Input and Output Monitoring, 6 J. LEG. STuD. 193 (1977). See also Charles D. Kolstad et al., Ex Post Liability for Harm vs. Ex Ante Safety Regulation: Substitutes or Complements?, 80 AM. ECON. REV. 888 (1990) (providing a model of environmental harm where the optimal policy combines ex ante regulation with ex post liability).

28. In the symmetric but far rarer case, we should reward those heroes who intervene to stop someone else from being victimized. It may also be argued that those who acquire a gun to defend themselves provide a benefit to their neighbors, in the sense that some criminals may be deterred by the threat of encountering an armed victim. The alternative view is that criminals will respond to widespread private armament in ways that will prove harmful to society, as in an arms race. In any event, survey evidence indicates that people generally feel less safe when their neighbors are armed. See David Hemenway et al., Firearms and Community Feelings of Safety, 86 J. CRIM. L. \& CRIMINOLOGY 121 (1995).

29. An external cost might arise even in the simple display of firearms if some people are unnerved by the thought, or indeed the actuality, that firearms are in the vicinity.

30. The punishment could be non-monetary, as is the case with a prison term. A prison term, however, requires real resources, including both the costs of maintaining the prisons and the opportunity costs of prison time to the inmates themselves. A payment equal to the value of the external cost sometimes is called a "Pigovian tax." With a monetary Pigovian tax that is costless to enforce, society (other than the perpetrator) is effectively rendered indifferent as to whether the gun misuse takes place or not. (There is still a distributional issue if the damaged party is not made whole through compensation, and of course, the administration of fines is not costless.) A prison term that provides the same incentives for perpetrators as a Pigovian tax, however, will no longer leave society 
An objection to such a direct, ex post liability structure might be that not all of those who misuse firearms will be caught and punished. In itself, however, imperfect enforcement does not imply the inefficiency of a liability regime, since fines can simply be scaled upwards for those who are caught, in inverse proportion to the probability of arrest and conviction. In this way, the expected penalty for would-be gun misusers will be the same, prior to deciding on gun use, as it would be if there were perfect enforcement. However, if our sense of justice requires punishment to be commensurate with the seriousness of the crime, then severe punishments are not acceptable for petty offenses even if such punishments are rarely imposed. ${ }^{31}$

The implementation of ex post sanctions is also costly. Gun misusers have to be identified, apprehended, tried, and the sentence carried out. To save on enforcement costs, a regime matching a low probability of being caught with a large punishment for those caught might be best, but again raises serious questions of justice. ${ }^{32}$

Even with perfect and costless enforcement, there are two reasons to believe that an ex post liability structure would be inadequate to the task of eliminating all uses of guns that are not, from society's perspective, worthwhile. The first reason is that in most instances the perpetrator of a gun crime is judgment-proof in the sense that he would be unable to pay a fine as large as the cost to the victim. Imprisonment and (in rare instances) execution take the place of fines in practice, but there is no guarantee that these punishments will be as great (from the perpetrator's perspective) as the harm to the victim and society. Implementing such punishments is also costly to the public. The second reason

indifferent to misuse, because of the resources that are consumed by prison time.

31. See Gary Becker, Crime and Punishment: An Economic Approach, 76 J. POL. ECON. 169 (1968); see also A. Mitchell Polinsky \& Steven Shavell, The Optimal Tradeoff Between the Probability and Magnitude of Fines, 69 AM. ECON. REV. 880 (1979) (noting that risk aversion complicates the tradeoff between the size of a fine and the probability that the fine is imposed); Steven Shavell, Criminal Law and the Optimal Use of Nonmonetary Sanctions as a Deterrent, 85 COLUM. L. REV. 1232 (1985). For a discussion of "just desserts" as a defining or limiting principle in sentencing, see NORVAL MORRIS, THE FUTURE OF IMPRISONMENT (1974); ANDREW VON HIRSH, DOING JUSTICE-THE CHOICE OF PUNISHMENTS: REPORT OF THE COMMITTEE FOR THE STUDY OF INCARCERATION (1976).

32. The possibility that innocent people might be wrongly convicted militates against the attractiveness of low probability-high fine enforcement regimes. Also, there is evidence that deterrence is enhanced further by an increase in the probability of punishment than by an increase in the severity of punishment, particularly among criminals. See FRANKLIN E. ZIMRING \& GORDON HAWKINS, DeterRenCE: THE Legal THReat In CRIME Control (1973); Michael K. Block \& Vernon E. Gerety, Some Experimental Evidence on Differences Between Student and Prisoner Reactions to Monetary Penalties and Risk, 25 J. LEG. STUD. 123 (1995); John Carroll \& Frances Weaver, Shoplifters' Perceptions of Crime Opportunities: A Process-Tracing Study, in THE REAsONING CRIMINAL: Rational Choice Perspectives on OfFending (Derek B. Cornish \& Ronald V. Clarke eds, 1986); Philip J. Cook, Research in Criminal Deterrence: Laying the Groundwork for the Second Decade, in CRIME AND JUSTICE: AN ANNUAL REVIEW OF RESEARCH (Norval Morris \& Michael Tonry eds., 1980). Finally, raising the stakes generally increases the social costs associated with punishment, as more effort is put into defending and prosecuting cases. On the costs of the death penalty, for instance, see PHILIP J. COOK \& DONna Slawson, The COSTS OF PRosecuting MuRder CASES in North Carolina (1993), and for a more general discussion, Bruce H. Kobayashi \& John R. Lott, Jr., Low-ProbabilityHigh-Penalty Enforcement Strategies and the Efficient Operation of the Plea-Bargaining System, 12 INT'L REV. L. \& ECON. 69 (1992). 
to doubt the ex post liability structure is that some potential violators are incapable of rationally weighing the costs and benefits of firearm misuse. Together, these two factors strengthen the case for bolstering ex post liability with $e x$ ante firearms regulations.

Practical limits on liability are often a problem in providing incentives for good behavior, and with respect to firearms, such constraints are pervasive..$^{33}$ Consider how much you would have to be paid to grant someone permission to shoot you. Most people would be unwilling to agree to such a "contract" for any amount of money, so it is not surprising that those who kill with firearms (or with other weapons, for that matter) are unable to pay the social costs of their activity. Even with perfect enforcement and a costless judicial system, then, there would be a "socially excessive" level of homicide under a regulatory regime that depended solely upon ex post liability. ${ }^{34}$ The problem is further exacerbated by an imperfect court system and by offenders who are effectively judgment-proof for other reasons, as in the case of a murder-suicide. ${ }^{35}$

The other difficulty with a reliance on ex post liability is that youths and mentally ill individuals might be irrational, choosing to misuse firearms even when it is clearly not in their best interest to do so. After-the-fact sanctions might have little influence on the behavior of such individuals, bolstering the case for a regulatory regime aimed at keeping guns away from children and the mentally ill. And otherwise responsible people may go through moments of rage, inebriation, depression, or "temporary insanity," when they too are less likely to respond as expected to the prospect of ex post punishments.

Therefore, even if all of those who misused guns were apprehended and punished, there would still be too much gun misuse from society's point of view. A preferable policy regime would complement ex post liability with some ex ante measures, provided that ex ante measures actually can reduce access to firearms to high-risk individuals. This conclusion is strengthened given the reality of costly and imperfect ex post enforcement.

\section{B. Taxing Ownership}

In practice, control measures take a variety of forms, from requirements for recordkeeping and licensing to outright prohibitions on certain types of guns and on sales to convicted felons. ${ }^{36}$ While remarkably little use of financial incentives is made, there are exceptions: For example, the fee for a concealed-

33. See Steven Shavell, The Judgment-proof Problem, 6 INT'L REV. L. \& ECON. 45 (1986).

34. Another difficulty that limits ex post liability concerns "marginal deterrence." Assume, for example, that the seemingly optimal punishment for aggravated rape is a life sentence. Faced with such a severe punishment, the rapist may decide that he has nothing to lose and something to gain (elimination of the witness) from killing his victim. See ZIMRING \& HAWKINS, supra note 32, at 72-74.

35. One approach to mitigating the limited liability problem is to extend the liability for gun misuse to the manufacturer or the seller of guns that are used in a manner that results in injury or death. Were such an extension of liability to occur, the legal market for firearms would be greatly proscribed.

36. BUREAU OF JUSTICE STATISTICS, supra note 23, at 132. 
carrying license is quite high in some states. ${ }^{37}$ It is instructive to consider what a comprehensive system of fees or taxes would look like. The taxes, designed to cover the marginal social costs of expected future gun misuse, would be equivalent to a set of actuarially fair premiums for the purchase of insurance against the costs of firearm fatalities. ${ }^{38}$

What would be the rough magnitude of such a tax or premium for a handgun owner? In 1994, there were about 13,000 handgun homicides. ${ }^{39}$ Making an allowance for the fact that some of the homicides were justifiable or in self-defense, assume that there are at least 10,000 unjustified handgun homicides per year. ${ }^{40}$ Take the value of a life, conservatively, to be $\$ 1$ million, and note that there are about 60 million handguns in private hands. ${ }^{41}$ That works out to about $\$ 167$ per gun per year, just to cover the cost of fatal shootings. Of course, some of the criminal homicides that are now undertaken with firearms might be committed with other weapons in the absence of a gun. But there appears to be a substantial "instrumentality effect" to firearms, such that otherwise identical assaults without guns lead to a sharp decrease in fatalities. ${ }^{42}$ Assume that the fatality "advantage" to firearms is $3: 1 .^{43}$ The appropriate average tax for a handgun owner, conservatively calculated, would still be a very substantial $\$ 100$ per year.

These rough calculations ignore the fact that individual gun owners differ in their propensity to misuse a gun. Ideally, each individual user would be charged a different premium based on both his propensity and the type of firearm and the likely use. However, such extreme differentiation is impractical; rather,

37. Concealed carrying license fees for four sample states are California- $\$ 150$, Texas- $\$ 140$, Florida-not to exceed \$85, and North Carolina-\$80. NRA Home Page, supra note 16; Michael J. Ybarra, A Town's Gun Permits Bring Cash and Controversy, N.Y. TimES, Feb. 9, 1996, at 14.

38. The experiment assumes no ex post liability. Otherwise, the optimal ex ante insurance regime would involve less than full insurance.

39. U.S. DEPARTMENT OF JUSTICE, FEDERAL BUREAU OF INVESTIGATION, CRIME IN THE UNITED STATES (1994).

40. Abraham N. Tennenbaum, Justifiable Homicides by Civilians in the United States, 1976-1990: An Exploratory Analysis 73-74, 78-94 (1993) (unpublished Ph.D. dissertation, University of Maryland (College Park)) (critiquing GARY KLECK, GUNS AND VIOLENCE IN AMERICA (1991) (discussing issues of definition and measurement of civilian justifiable homicides)).

41. There is a wide range of estimates for the value of life. W. Kip Viscusi, Strategic and Ethical Issues in the Valuation of Life, in STRATEGY AND CHOICE 380 (Richard J. Zeckhauser ed., 1992) (noting value-of-life estimates from $\$ 1$ million to more than $\$ 10$ million); Philip J. Cook, Notes on the A vailability and Prevalence of Firearms, 9 AM. J. PREVENTIVE MED. 9, 33 (Supp. 1993) (estimating that "the current volume of firearms in private hands is probably 150-200 million, approximately one third of which are handguns").

42. Franklin E. Zimring, The Medium is the Message: Firearm Calibre as a Determinant of Death From Assault, 1 J. LEG. STUD. 97 (1972); Franklin E. Zimring, Is Gun Control Likely to Reduce Violent Killings?, 35 U. CHI. L. REV. 721 (1968); see also Cook \& Moore, supra note 22, at 273-75. A tax or prohibition on handguns might lead some people to switch to long guns, which could also be subject to a Pigovian tax. Gary Kleck, Handgun-Only Gun Control: A Policy Disaster in the Making, in Firearms AND ViolenCE: IsSUES of PUbliC POLICY (Don B. Kates ed., 1984).

43. The death rate in gun robberies is three times as high as in knife robberies, and 1,000 gun robberies cause about three times as many deaths as 1,000 nongun robberies. Philip J. Cook, Robbery Violence, 78 J. CRIM. L. \& CRIMINOLOGY 357, 374 (1987); see also Zimring, Is Gun Control Likely to Reduce Violent Killings?, supra note 42 , at 728. 
premiums can be based on only a few characteristics, just as automobile insurance premiums depend on only a few variables. ${ }^{44}$

For mature individuals with spotless records, the actuarially fair tax or premium for almost any firearm would be rather small. There is little likelihood that such individuals would use the firearm for violent crime against strangers, though there is the possibility of an accident, an intentional shooting when a threat is falsely perceived, or transfer of the gun to a criminal via theft. ${ }^{45}$ The premium could be adjusted for the storage situation; for example, guns kept in cars would be assessed a higher premium because of the enhanced likelihood of theft. The premium might also depend on the amount of training or experience that the owner has with firearms. Other variables that might affect the premium include age, sex, use of drugs or alcohol, rural or urban residence, and whether or not the gun is carried in public. ${ }^{46}$

For some individuals, the external benefits of gun possession outweigh the costs, so the optimal ex ante regulatory regime could involve a public subsidy to gun ownership and training, as is in fact the case with law-enforcement officers. For other users, however, the actuarially fair premium would be prohibitive, as in the case of violence-prone urban youths. ${ }^{47}$

As for the appropriate adjustment of the premium for the type of gun, two principles apply. First, guns that are readily carried concealed would be charged a higher rate because of their relatively high risk of being used in crimes. Second, the premium would increase with the lethality of the weapon, measured by such factors as the velocity and caliber of the bullets, size of the magazine, rapidity of fire, and so forth. ${ }^{48}$

44. For an examination of the optimal tax when individuals differ in the extent to which their consumption of a good creates an externality, but where the tax must be uniform across all individuals, see Peter A. Diamond, Consumption Externalities and Imperfect Corrective Pricing, BELL J. ECON. 526 (1974).

45. If the criminal ends up hurting someone with a firearm, perhaps that liability should not be held against the initial purchaser. But if the question is to determine the marginal social impact of an additional firearm, the possibility of theft and then criminal misuse must be taken into account. Suicide is also a risk with a firearm. On the marginal risk of suicide due to possession of a gun, see Arthur $L$. Kellermann et al., Gun Ownership as a Risk Factor for Homicide in the Home, 329 NEw ENG. J. MED. 1084 (1993). The premium also should be adjusted downward for the value of the marginal deterrence of crimes attributable to a gun in private hands, and upwards for the external costs of accidents and non-fatal shootings.

46. Five variables in addition to gun ownership, demographic characteristics, and place of residence are associated with an increased risk of homicide in the home: home rented, case subject lived alone, any household member ever hit or hurt in a fight in the home, any household member ever arrested, and any household member used illicit drugs. Id. at 1087.

47. Many people who have engaged in repeated violent behavior nevertheless have no convictions on their record, and therefore "guns could be denied, under selective gun control measures such as permissive licensing laws, to about half of the people who will commit homicides in the near future." Gary B. Kleck, Policy Lessons From Recent Gun Control Research, 49 LAW \& CONTEMP. PROBS. 35 (Winter 1986). This "loophole" could be narrowed by seeking more convictions against repeated domestic violence offenders, id. at 41 , and also by allowing criminally violent acts by a juvenile to remain on his or her adult record.

48. In the past several years, several assault weapons bans have been proposed by lawmakers. The following types of firearms/bullets were proposed banned: weapons with pistol grips allowing the spraying of fire from the hip; weapons containing devices designed to feed more than ten rounds of 
While a tax scheme such as that described above may not be feasible for a variety of reasons, ${ }^{49}$ it provides a framework for evaluating other schemes. The current prohibition against selling firearms to convicted felons, for instance, might be seen as a practical device for implementing the socially optimal tax for that class of users, which would be so high that none could pay. Greater restrictions on handguns than on other firearms (and similarly for extremely lethal firearms) would also appear to provide a rough-and-ready method for making the tax sensitive to the higher associated risk. Interestingly, the National Firearms Act of 1934 effectively banned machine guns and other weapons of mass destruction through the device of imposing a then-prohibitive $\$ 200$ tax on transfers. ${ }^{50}$

The rationale behind preemptive firearm regulation applies to other situations of negative externalities. When ex post sanctions are uncertain or ineffective, ex ante regulation may well be socially desirable. Sanctions against drunk driving are partly motivated by similar reasoning. It is unsafe driving that is the actual social problem. A blood alcohol content in excess of the legal limit is evidence that is suggestive, though far from conclusive, that a driver is endangering others. But since not all unsafe driving can be monitored and sanctioned, regulations on driving while intoxicated are sensible. James Jacobs, in Drunk Driving: An American Dilemma, makes precisely this connection between drunk-driving prohibition and gun control:

$[\mathrm{T}]$ he offense of drunk driving is much like illegal possession of a handgun. A particular handgun possessor may not pose a specific risk, but the legislature has chosen not to wait until a lethal threat materializes.... Clearly, society wants to prevent dangerous driving. The existence of drunk driving laws refiects a judgment that the traffic laws that proscribe various forms of dangerous driving bring the criminal law into the picture too late. The prohibition against drunk driving is an effort to prohibit conduct that might lead to dangerous driving. Under this preemptive strategy, it does not matter whether the drinking driver is actually driving dangerously at the time he is stopped. ${ }^{51}$

\footnotetext{
ammunition; and body armor-piercing bullets and other flesh-tearing bullets such as the "Black Talon" and "Rhino-Ammo." Helen Dewar, Senate Votes for Proposal to Curtail Spread of Assault Weapons, WASH. POST, Nov. 10, 1993, at A22; Daniel Patrick Moynihan, Just Bite the Bullets!, WAsH. POST, Jan. 5, 1995, at A29. Assault weapons banned under the Violent Crime Control and Law Enforcement Act of 1994 included semiautomatic rifles and pistols with the ability to accept a detachable magazine and possessing at least two of four additional features, and semiautomatic shotguns possessing at least two of five features (one of which is an ability to accept a detachable magazine). Dorothy Schrader, The Assault Weapons Ban: Review of Federal Laws Controlling Possession of Certain Firearms, CRS REPORT FOR CONGRESS (Dec. 1, 1995).

49. Politics aside, the problem of collecting the tax is not trivial. All owners would be required to register their guns when they were purchased and report to the authorities if they were stolen or otherwise transferred. Compliance with this registration system would presumably be lower than with motor vehicles, due to the relative difficulty of detecting an unregistered firearm.

50. Zimring, Firearms and Federal Law, supra note 7, at 138.

51. JAMES JACOBS, DRUNK DRIVING: AN AMERICAN DILEMMA 60 (1989). Ironically, anti-guncontrol advocate Wayne $R$. LaPierre makes an analogy to the victimless crime of drunk driving in calling for improved enforcement of ex post punishments: "When those who insist that gun laws conform to motor vehicle laws begin to call for holding the individual accountable for gun-related crimes, as they do with drunk driving, then we will have a true comparison between motor vehicles and firearms." LAPIERRE, supra note 5, at 67.
} 
Unlike drunk driving, some uses of guns have positive externalities, and there has been much debate whether gun-control measures are harmful in the sense of preempting a substantial number of these virtuous uses. ${ }^{52}$ Some gun advocates go so far as to assert that repeal of regulations on guns would result in a safer society (due to the general deterrent value of an armed public) and one more robust in its resistance to tyranny. ${ }^{53}$ Of course these considerations should be factored into the calculus, but only insofar as they are valid. The available evidence, far from establishing the validity of either of these claims, suggests instead that they are incorrect. ${ }^{54}$

\section{IV \\ REGULATION OF FORMAL GUN MARKETS}

The existence of significant external costs from firearm misuse and the inadequacy of ex post liability measures to internalize those costs together provide an economic rationale for preemptive regulation of firearms. Such a rationale, however, is a necessary rather than sufficient condition for justifying gun-control measures. Regulatory regimes are themselves socially costly, in terms of the resources that go into implementing, enforcing, evading, and complying with regulations. The actual costs and benefits of specific regulations therefore should be considered and compared with alternative regulatory regimes.

Gun-control measures typically impose some burden on law-abiding citizens who enjoy gun sports or want a gun for protection. The debate over gun control often focuses on whether this burden is justified by a reduction in the costs of crime and violence. Prominent among the arguments against controls are those that rely on claims of perversity or futility. To evaluate these claims, it is useful to analyze the market for firearms. We do so first in general terms and then in the context of considering the likely consequences of three types of controls. Our main purpose here is to help provide structure to the debate, but there is also a substantive conclusion: The loopholes in the regulatory structure are problematic but not sufficiently broad to support the "futility" claim.

\section{A. The Market for Guns}

Because there are already so many guns available, it might be thought that the current gun trade would have little to do with the social costs of gun misuse.

52. "[I]f self-protection with a gun is commonplace, it means that any form of gun control that disarms large numbers of prospective victims ... will carry significant social costs in terms of lost opportunities for self-protection." Gary B. Kleck \& Marc Gertz, Armed Resistance to Crime: The Prevalence and Nature of Self-Defense With a Gun, 86 J. CRIM. L. \& CRIMINOLOGY 150, 151 (1995).

53. Jeffrey R. Snyder, $A$ Nation of Cowards, 113 PUB. INTEREST 40 (Fall 1993).

54. On the impact of liberalized concealed-carry laws, for instance, see David McDowall et al., Easing Concealed Firearms Laws: Effect on Homicide in Three States, 86 J. CRIM. L. \& CRIMINOLOGY 193 (1995). 
The large existing stock of firearms in the United States would seem to satisfy the demands of criminals for a long time to come:

[T] he 200 million guns now in circulation would be sufficient to sustain roughly another century of gun violence at the current rates, even assuming that each gun was used once and only once for some nefarious purpose and that all additions to the gun supply were halted permanently and at once. Because of the large number of guns already in circulation, the violence-reductive effects of even fairly Draconian guncontrol measures enacted today might well not be felt for decades. ${ }^{55}$

But how do some of those 200 million guns find their way into the hands of criminals? Careers in violent crime are typically quite short, and each new cohort of youths with a penchant for violence must obtain their guns somehow, either new guns from licensed dealers or used guns from current owners. If "all additions to the gun supply were halted," then the effect would be to greatly increase the value of used guns, ${ }^{56}$ with the result that it would become harder to steal and much more expensive to buy (or own) a gun. The result would be that a smaller percentage of those violent cohorts would be armed at any one time. $^{57}$ Thus, the large stock of guns is insufficient in itself to render gun control futile.

But what does the market for firearms look like? There are about 4.5 million new guns sold each year and a comparable number of transactions involving used guns. ${ }^{58}$ Transactions conducted through federal firearms licensees ("FFLs") form the primary market for guns. ${ }^{59}$ Almost all initial retail sales of legally manufactured or imported new guns take place through FFLs. (The main exception is guns that are stolen before sale. ${ }^{60}$ ) Some FFLs also sell used guns. Once a gun is in private hands, it can be transferred in a wide variety of ways. Transfers of new or used guns by non-licensed individuals constitute the secondary gun market. ${ }^{61}$ Classified ads in newspapers and in gun

\section{3.}

55. James D. Wright, Ten Essential Observations on Guns in America, SoC'Y, Mar.-Apr. 1995, at

56. For an analogy, consider the auto market, where there are 121.1 million vehicles "in circulation." STATISTICAL ABSTRACT OF THE UNITED STATES (1995). If all manufacture and import ceased overnight, used cars would jump in value and most teenagers would be priced out of the market. For example, when President Clinton proposed imposing a 100\% tariff on thirteen Japanese imports, it was predicted that used-car values for these models would skyrocket. Daniel Kadlec, Car in Garage may be Money in Bank, USA TODAY, May 17, 1995, at B3; Kathy M. Kristof, U.S.-Japan Trade Showdown; A Risky Road; Threat of Huge Tariffs Could Pose Problems for Buyers, LA TIMEs, May 17, 1995, at D1.

57. Of course, it could be argued that those with a penchant for violence would be willing to pay any price for a gun. That seems unlikely, given that the typical robber or even drug dealer has a much smaller income than the typical gun owner. A recent study of gang members in Rochester found that only a third of them had a gun. Beth Bjerregaard \& Alan J. Lizotte, Gun Ownership and Gang Membership, 86 J. CRIM. L. \& CRIMINOLOGY 37 (1995). And most robbers apparently do not have a gun available: Despite the evident advantage of using a gun in robbery, only about $25 \%$ of street robberies are committed with guns. U.S. DEPARTMENT OF JUSTICE, CRIMINAL VICTIMIZATION IN THE UNITED STATES 76, 83 (1992).

58. Cook, supra note 41 , at 33-34. 1995).

59. Philip J. Cook et al., Regulating Gun Markets, 86 J. CRIM. L. \& CRIMINoloGY 59, 68 (Fall

60. See generally Cook \& Blose, supra note 7 , at 84 .

61. Cook et al., supra note 59 , at 68 . 
magazines, gun shows (which include FFLs and nondealers), personal connections, and thefts all facilitate transactions in the secondary market. Theft is surprisingly common, with approximately 500,000 guns stolen per year. ${ }^{62}$ About sixty percent of all (new and used) gun transactions are in the primary market. ${ }^{63}$ Youths and felons, however, are much more likely to acquire guns informally, from friends, from family, or "on the street."

Many of the transactions that occur in the secondary market are not formally recorded but are nonetheless legal. The main legal requirement on the seller of a used gun is that the gun not be transferred to someone who is known to be, or should reasonably be known to be, underage, a convicted felon, or in one of the other restricted categories. ${ }^{65}$ (Generally, it is legal for someone to give or loan guns to underage members of his or her own family.) FFLs sometimes engage in illegal transfers, to known felons, for example. So another useful dichotomy for firearm transactions is the formal market, which consists of legal sales by FFLs, and the informal market, which is composed of any illegal transfers (by FFLs and others) plus legal but unrecorded transactions involving non-dealers. The informal market, therefore, is that part of the market that exists either outside of, or in contravention to, legal restrictions on guns: the unregulated and the illegal firearms transactions.

FIGURE 1

THE FLOW OF FIREARMS ${ }^{66}$

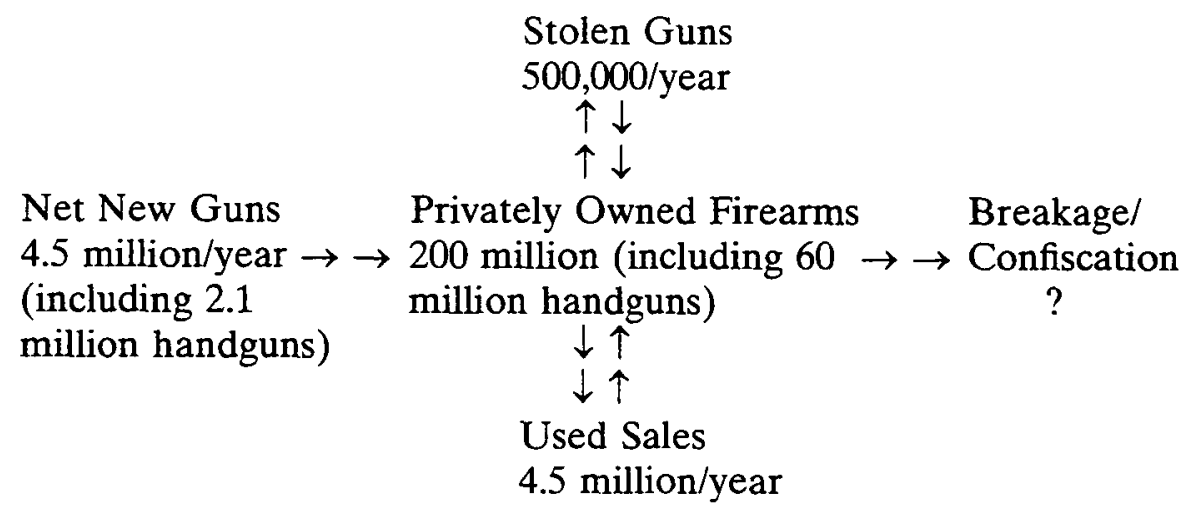

62. Id at 81 .

63. Id. at 69 .

64. In one survey, about $15 \%$ of convicted felons said they acquired their most recent handgun in the primary market; another survey indicated that an even smaller percentage of youths used the primary market to acquire guns. See JAMES D. WRIGHT \& PETER H. ROSSI, ARMED AND CONSIDERED DANGEROUS: A SURVEY OF FELONS AND THEIR FIREARMS 183, 185 (1986); Cook et al., supra note 59 , at 70 .

65. 18 U.S.C. $\& 922$ (d)(1) (1994) (prohibiting sales to felons); id. $\$ 922(b)(1)$ (prohibiting sales to youths).

66. See Cook \& Moore, supra note 22; see also Cook, supra note 41. 
Figure 1 is a schematic representation of the stock and flows of guns in the United States. There do not seem to be reliable estimates of the number of guns that leave the U.S. stock every year through breakage or international smuggling. ${ }^{67}$ "Net New Guns" includes new domestic production, minus exports, plus imports. The informal market thus provides an important way around some gun regulations. Nonetheless, economic analysis of the formal and informal markets suggests that they are linked: The terms of trade in the informal market may be affected by regulations imposed on the formal market. We explore this linkage in an analysis of three types of gun regulation: excise taxation; a ban on particular types of weapons; and a reduction in the number of FFLs.

\section{B. Excise Taxation}

The federal government has long imposed a special excise tax on the production and import of firearms and ammunition. ${ }^{68}$ This tax is collected at the point of shipment from the manufacturer or importer, and presumably increases the wholesale and retail prices charged for new firearms. While the rate is currently just ten or eleven percent (depending on the type of gun), some have argued that it should be increased to bring the tax in line with the social costs attributable to firearms in private hands, like a Pigovian tax. ${ }^{69}$ Analyzing the possible consequences of such an increase is interesting in itself because the excise tax occasionally shows up on the political agenda ${ }^{70}$ and because some other control measures, most notably a purchase-permit requirement, also increase the effective price of buying a gun in the formal market.

To be specific, suppose that Congress imposed an additional excise tax on every firearm produced or imported, such that the retail prices of guns increase by $\$ 25 .^{71}$ Sales of new guns would fall, and some potential buyers who would otherwise have bought a new gun from an FFL would instead turn to the informal market to look for a used gun. This upward shift in demand for used guns would result in a larger flow of transactions for used guns at somewhat higher prices than before the tax increase, as shown in Figure 2. ${ }^{72}$ Not shown

67. James D. Wright et al., UNDER THE GUN: WeAPONS, CRIME, AND VIOLENCE IN AMERICA ch. 2 (1983).

68. Revenue Act of 1918 , ch. $18 \S 900(10), 40$ Stat. 1057, 122 (codified at I.R.C. $\S 4181$ (1994))

69. Representative Mel Reynolds (D-ILL.) and others proposed that Congress increase the $10 \%$ excise tax on handguns to $20 \%$ and the $11 \%$ tax on all other firearms to $21 \%$, citing high hospitalization expenses as a result of firearms injuries. Does Congress Hear the Gunfire?, WASH. POST, March 5, 1993 , at A20.

70. Senator Daniel Moynihan's 1994 health-care proposal called for increasing the handgun ammunition excise tax from $11 \%$ to $50 \%$. Spencer Rich, Congressional Health Plans, WASH. POST, June 12, 1994, at A8.

71. Excise taxes of the magnitude suggested earlier for a Pigovian tax, say $\$ 100$, would result in a good deal of evasion, perhaps through gun smuggling or through home production. For relatively small levels of excise taxes, however, these forms of evasion are likely to remain minor.

72. Figure 2 depicts a formal market supply curve that is horizontal, as would be the case if gun manufacturing were a competitive, constant-cost industry. The discussion of the effects of an excise tax is not affected, however, by the precise shape of the formal market supply curve. 
in this figure are the long-run consequences, whereby the reduction in sales of new guns would result in a smaller inventory in private hands, and hence a reduction in the supply of used guns. This supply shift would push prices up still further in the informal market. This is standard economics and would apply equally well to other markets for consumer durables.

FIGURE 2

THE EFFECT OF AN EXCISE TAX

Formal Market

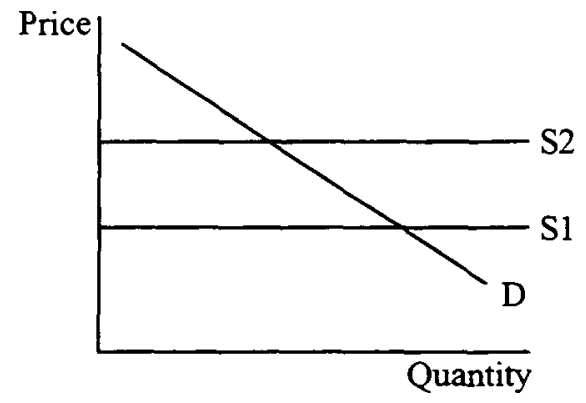

Informal Market

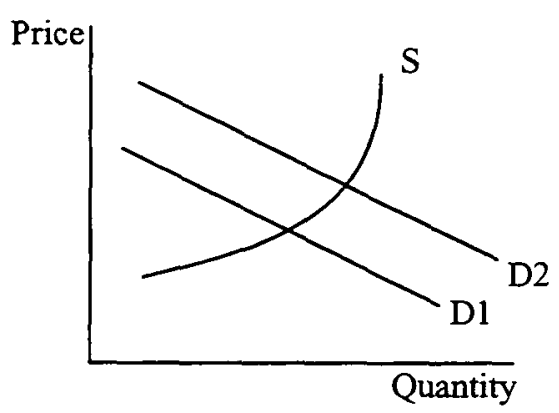

If the excise tax is to be an effective preventive measure, then some violent youths and other dangerous people must be persuaded by higher gun prices to "economize" on gun possession-that is, to reduce the percentage of their violent "careers" in which they have ready access to a firearm. This economizing might take various forms: Faced with higher prices, they might be quicker to sell guns they owned or stole; they might be slower to buy a gun during times when they were without one; and they might be more inclined to protect their guns from theft or confiscation by leaving them at home. ${ }^{73}$ All of these responses are plausible: Some research shows that youthful criminals are often active as both buyers and sellers in the informal gun market, and are well aware of what a gun is worth. ${ }^{74}$ While some dangerous individuals, including major drug dealers, have high incomes and hence a relatively inelastic demand for guns, most youthful criminals, even those who sell drugs occasionally, have small incomes. $^{75}$ For them, keeping a gun comes at the cost of satisfying other

73. A further margin for economizing involves more intensive use of existing guns, including perhaps more crimes per gun and more frequent loans of weapons.

74. JOSEPH F. SHELEY \& JAMES D. WRIGHT, GUN ACQUISITION AND POSSESSION IN SELECTED JUVENILE SAMPLES 7-8 (1993); Cook et al., supra note 59, at 63-65.

75. The larger the portion of a consumer's budget that is devoted to a (non-inferior) good, the more elastic the consumer's response to a price change for that good, in general, because the "income effect" of a price change is likely to be large. On the incomes of those in the illegal drug trade, see PETER REUTER ET AL., MONEY FROM CRIME 64-66 (1990). A complementary economic perspective 
important wants.

Supposing that the excise tax is effective in reducing gun possession by dangerous people, then it becomes relevant to know whether the type of weapon matters in perpetrating crime and violence. Those who assert the futility of gun control believe that "guns don't kill people, people do," suggesting that a knife or club will serve just as well as a gun in the hands of a determined perpetrator. The evidence, however, indicates that the type of weapon used in assault or robbery matters a great deal in influencing the likelihood that the victim will die-guns are simply more lethal than other readily available weapons. ${ }^{76}$ There is, as noted above, an important instrumentality effect, in the sense that the outcome of a violent confrontation is determined by the instrument used as well as the intent of the perpetrator.

The argument that gun-control measures, including an increased excise tax, would not just be futile, but actually perverse, rests on additional claims about the efficacy of guns. Proponents of this argument contend that the type of weapon matters a great deal in self-defense uses: As potential victims substitute away from guns because of controls, they become more vulnerable. ${ }^{77}$ These proponents also argue that widespread gun ownership and carrying have a general deterrent effect on violent criminals and reduce robbery and assault rates. Under this argument, the increased excise tax is worrisome, for it might result in a reduction in the prevalence of gun ownership. Victims would be less likely to have a gun handy to fend off attack, and there would be an attenuation of whatever deterrent effect is generated by widespread private ownership.

We have now identified the essential points of contention concerning the hypothetical consequences of an increase in the excise tax, which are summarized in Table 1. The columns labeled "Pro Control Position" and "Anti Control Position" are not intended to characterize the views of any individual or group, but rather to describe the logical extremes. In principle, these are all matters of fact rather than ideology, and hence subject to empirical research. If anti-control claims 1-3 prove to be correct, then the increase is futile. If claims $4-5$ are also correct, then the increase is perverse. If, on the other hand,

\footnotetext{
on the gun market follows from the principle that in a well-functioning market, a scarce commodity will be allocated to its highest valued uses. The relevant measure of value in this case is what individuals are willing to pay. Since new and used guns are close substitutes for many gun owners, an increase in the excise tax on new guns would increase the value of used guns. That in turn would engender a redistribution of the stock of guns to higher-valued uses through market processes. Of those who currently own guns, is it youths or adults who tend to place a higher monetary value on them? Poor households or those with more comfortable incomes? Sport shooters looking to add a tenth gun to their collection or individuals who decide they need to acquire a gun to protect them from crime? Answers to questions of this sort will influence the effect of the excise tax on crime.

76. Zimring, The Medium is the Message, supra note 42, at 98; Zimring, Is Gun Control Likely to Reduce Violent Killings?, supra note 42, at 728; see generally Philip J. Cook, The Technology of Personal Violence, in 14 CRIME AND JUSTICE: AN ANNUAL REVIEW OF RESEARCH 1 (Michael Tonry ed., 1991).

77. Note that if the type of weapon matters in defensive uses, as gun-control opponents assert, then it seems logical that it would also matter in offensive uses.
} 
the pro-control views are correct, then the tax increase would have the effect of reducing the social costs of crime and violence.

TABLE 1

Hypothetical CONSEQUenCES of ExCISE TAX on Guns

$\begin{array}{ll}\begin{array}{l}\text { Pro-Control } \\ \text { Position }\end{array} & \begin{array}{l}\text { Anti-Control } \\ \text { Position }\end{array} \\ \text { Large increase } & \text { Small increase } \\ \text { Decrease } & \text { No effect }\end{array}$

(1) Prices in the informal market

(2) Prevalence of possession by dangerous people

(3) Instrumentality effect of gun use by perpetrator

(4) Prevalence of possession by potential victims

(5) Deterrence and selfdefense efficacy of gun ownership

Criminal attack Type of weapon rarely is often more deadly with gun has effect on deadliSmall reduction ness of attack Large reduction

Small Large

\section{Ban on Particular Types of Firearms}

Not all types of firearms pose an equal threat to domestic tranquility, and some are more tightly regulated than others. The more stringent regulations have been applied to types of firearms not ordinarily used in hunting, and fall into two categories: weapons of "mass destruction" and handguns. Federal law governing the first category was applied to submachine guns, hand grenades, sawed-off shotguns, and other "gangster weapons," transfers of which were subject to high taxes and registration by the National Firearms Act of $1934 .^{78}$ Furthermore, recent federal law has banned commerce in certain brands of "assault weapons," military-style firearms that among other characteristics have high-capacity magazines. ${ }^{79}$

The prohibition on weapons with the capacity for mass destruction is readily justified in terms of both social cost from misuse and relative lack of legitimate benefit. While such firearms pose a great danger to the community, they have little value to sportsmen (except as novelty items) or to those who seek protection from crime. ${ }^{80}$ But do these prohibitions accomplish their purpose?

78. National Firearms Act, 26 U.S.C. $\S 5811,5841$ (1995).

79. 18 U.S.C. $\S 921(\mathrm{a})(30)(\mathrm{A})(1994)$. The definition of an "assault weapon," and to some its seeming arbitrariness, has been prominent among the arguments mustered against the assault weapon ban. See, e.g., David B. Kopel, Assault Weapons, in Guns: Who Should Have Them? 159 (David B. Kopel ed., 1995); LAPIERRE, supra note 5, at 52-67.

80. Of course, there are some private militias that want military-style weapons to prepare for what they see as just combat against illegitimate government authorities. 
Legal restrictions create a profit opportunity that mobilizes the informal market; prohibitions are circumvented through home manufacture (converting semiautomatic rifles to fully automatic or sawing off a regulation shotgun), the black market trade in military weapons, and other means. But there seems little doubt that the National Firearms Act was effective in suppressing the Tommy gun in the 1930s and that automatic weapons are even today relatively rare in criminal assault cases. ${ }^{81}$ Ex ante gun prohibitions have not been futile in restricting access to the most dangerous weapons.

A second important distinction in gun regulation is between handguns and long guns. The Gun Control Act of 1968 set a higher minimum age for purchasers of handguns than long guns; ${ }^{82}$ recently, the Brady Law required states to implement a background check of handgun purchasers if such a system was not already in place. ${ }^{83}$ Several jurisdictions, including The District of Columbia and Chicago, have taken a large additional step, effectively banning private transfer and acquisition of handguns. ${ }^{84}$

What is the rationale for discriminating between handguns and long guns? Presumably because handguns are more convenient to carry and easier to conceal, they are far more likely than shotguns or rifles to be used in crime: While only one-third of the private stock of firearms are handguns, eighty percent of gun homicide and ninety percent of gun robberies are committed with handguns. ${ }^{85}$ While handguns are well adapted for use against people, they have a more limited role in sport than long guns. Both sides of the cost-benefit ledger thus appear to favor relatively stringent regulation of handguns.

However, the "perversity" argument has been forcefully asserted for this approach to regulation. Gary Kleck argues that a regime that is effective in denying handguns to violent people while giving them access to long guns would suffer an increase in homicides because rifles and shotguns tend to be more lethal than handguns. ${ }^{86}$ There are really two assertions here: first, that many violent people would substitute long guns (rather than knives or clubs) for handguns and, second, that the instrumentality effect would govern the results of this substitution (with more lethal weapons would come a higher probability of death in assault). While plausible, there is no direct evidence in support of Kleck's dire prediction. Indeed, the available evidence suggests that long-gun

81. GARY B. KLECK, POINT BLANK: GUNS AND VIOLENCE IN AMERICA 67-70 (1991).

82. 18 U.S.C. ₹ 922 (b)(1) (1994).

83. Id. § $922(\mathrm{~g})(2)$.

84. Edward D. Jones, The District of Columbia's "Firearms Control Regulations Act of 1975": The Toughest Handgun Control Law in the United States-Or Is It?, 455 ANNALS AM. ACAD. POL. \& SOC. SCI. 138 (May 1981).

85. Cook, supra note 76, at 23; Cook \& Moore, supra note 22, at 270 (indicating that for aggravated assaults and rape, if a gun is involved, more than $90 \%$ of the time it is a handgun).

86. Kleck, supra note 42 , at 167-99. 
assaults have about the same death rate as handgun assaults. ${ }^{87}$ Furthermore, in terms of concealability, long guns are poor substitutes for handguns. ${ }^{88}$

\section{Reduction in the Number of FFLs}

In 1993, the Violence Policy Center published a report noting the extraordinary increase in the number of FFLs during the 1980s, the result being "more gun dealers than gas stations." 89 But since then, the number of dealers has declined dramatically, from 261,000 in 1993 to 168,000 in September of $1995^{90}$ (and a projected level of $100,000-120,000$ by $1998^{91}$ ). The explanation for this remarkable turnaround is in two parts. First, the Bureau of Alcohol, Tobacco and Firearms ("BATF") implemented a stricter review of FFL applicants to ensure that they had a place of business and did not have a serious criminal record. ${ }^{92}$ Second, the Brady Law increased the fee for a new license from $\$ 30$ for the first three years to $\$ 200 .^{93}$

Even these new requirements are not particularly onerous for a large retail dealer. But under the relatively permissive BATF regime of the 1980 s, many individuals who were not really in the business of selling firearms found it convenient to obtain a license, simply because it gave them the right to purchase guns by mail-order for their own use. ${ }^{94}$ Another group of FFLs, the so-called "kitchen table dealers," lacked a storefront but did sell guns on occasion. ${ }^{95}$ The increased fee and tighter requirements are sufficient to eliminate many of these marginal businesses.

What are the likely effects of the reduction in the number of dealers? With more than 100,000 FFLs still in business, including the larger sporting-goods stores and other high-volume outlets, there should be little effect on competition

87. See Cook, supra note 76 , at 24.

88. See David B. Kopel, Hold Your Fire: Gun Control Won't Stop Rising Violence, POL'Y REV., Winter 1993, at 58 (noting the difficulty in concealing "assault weapons" in arguing against the ban of such firearms).

89. Violence Policy Center, More Gun Dealers than Gas Stations (1992).

90. U.S. GEN. ACCT'G OFFICE, FEDERAL FIREARMS LICENSEES: VARIOUS FACTORS HAVE CONTRIBUTED TO THE DECLINE IN THE NUMBER OF DEALERS 5 (March 1996).

91. Interview with William T. Earle, Deputy Associate Director, ATF (Mar. 6, 1996).

92. In August 1993, the Clinton Administration instructed ATF to take its regulatory responsibilities more seriously, in particular to (1) improve "the thoroughness and effectiveness of background checks in screening dealer license applicants," (2) make the "premises' requirement of the statute more meaningful by increasing field checks" and using "other procedures to verify compliance," (3) review sanctioning policies to determine the desirability of "adding the option of license suspension for certain violations," and (4) expand the use of "cooperative agreements with State [sic] and local law enforcement agencies." Memorandum from President Clinton on Gun Dealer Licensing to the Secretary of the Treasury, 29 WEEKLY COMP. PRES. DOC. 1605 (1993).

93. Brady Handgun Violence Prevention Act, 18 U.S.C. $\$ \$ 921-922$ (1994). It should also be noted that several states began running tax-compliance checks with their FFLs. In North Carolina and Alabama, for example, state government officials determined that a large percentage of FFLs had not paid the annual state fee of $\$ 50$ required for selling firearms. Rather than pay this fee, some FFLs chose to turn in their licenses. Stuart Dabbs, How North Carolina Can Better Regulate Gun Dealers (1994) (unpublished M.P.P. thesis, Duke University).

94. ViOLENCE POLICY CENTER, supra note 89, at 21.

95. Id. 
or prices in most communities. But it seems quite likely that the FFLs who have failed to renew their licenses under the new rules include a disproportionate number of scofflaws-those who sell guns without keeping records or who sell to minors and felons. Further, the reduction in the number of FFLs reduces the regulatory burden on the BATF and creates an opportunity to regulate the remaining FFLs more closely in the effort to discourage illicit sales.

What difference would tighter regulation make for crime? Survey evidence suggests that even during the 1980s the secondary market was the main source of guns for criminals and youths. ${ }^{96}$ Still, FFLs have been a nontrivial source of illicit transactions. Consider these bits of evidence:

(1) From time to time there is an arrest of an FFL who has been in the business of selling large quantities of guns illegally. For example, in Tennessee an FFL was arrested in the early 1990s after illegally selling 10,000 to 15,000 guns over the course of several years. ${ }^{97}$

(2) In the first year following implementation of the Brady Law waiting period, 41,000 would-be buyers were prevented from purchasing from FFLs. $^{98}$

(3) FFLs have also been an important source to the gun runners. In 1993, Virginia, which had long been a principal source of handguns in the Northeastern cities, implemented a law limiting buyers to no more than one handgun purchase per month. ${ }^{99}$ A recent evaluation demonstrates that after implementation of this rule, guns from Virginia constituted a much smaller percentage of guns confiscated in New York and other Northeastern cities. ${ }^{100}$

A reduction in the number of scofflaw FFLs makes it more difficult for illicit buyers to obtain guns through that channel. As a result, some will forego purchasing a gun, and some will acquire second-hand guns through other informal means. ${ }^{101}$ The likely consequence is a downward shift in the effective demand for new guns, and an upward shift in the demand for used guns. The long-term result would be a reduction in the number of guns in private hands and a more active secondary market with higher prices.

96. SHELEY \& WRIGHT, supra note 74 , at 6-7.

97. Bruce Henderson, 5 Charged in Sale of Illegal Guns, CharlotTe ObSERver, Mar. 3, 1993, Metro, at $1 \mathrm{C}$.

98. Bureau of Alcohol, Tobacco, and Firearms, One-Year Progress RePORT: BRady HaNdGun Violence PREVENTION ACT app. (Feb. 28, 1995).

99. VA. CODE ANN. § 18.2-308.2:2(Q) (1996) (but allowing additional purchases, for example, as part of collections, after enhanced background checks).

100. Douglas S. Weil \& Rebecca C. Knox, Effects of Limiting Handgun Purchases on Interstate Transfer of Firearms, 275 JAMA 1759 (1996) ("The likelihood that a traced gun recovered anywhere in the nation was acquired in Virginia relative to another southeastem state, for firearms purchased after the 1-gun-a-month law took effect compared with guns prior to enactment of the law, was reduced $36 \% \ldots . . . "$.

101. Some proscribed buyers may already possess one or more firearms, so that for these individuals the inability to purchase a new weapon does not imply reduced access to a gun. And, of course, tighter regulation of dealers will not completely eliminate illicit sales by FFLs. 
A "futility" claim concerned with tighter enforcement of regulations that results in fewer scofflaw FFLs again would have to be based on the dubious assumptions that prices do not matter to youths and criminals and, more fundamentally, that the type of weapon has little effect on the likely outcome of violent encounters. There appear to be no grounds for "perversity" arguments: Legitimate purchasers are little affected by screening out kitchentable dealers and tightening the regulation of remaining FFLs.

\section{$\mathrm{V}$}

\section{Formal MARKET REgUlations AND VARIETIES OF DISCRIMINATION}

The previous discussion demonstrated the potential for formal-market regulations to raise prices of firearms in the informal market, thus reducing the number of transactions. However, most gun-market regulations do not have the intent of causing across-the-board price increases. Rather, they are designed to discriminate among different categories of purchasers (by criminal record, for example) and among different types of firearms. Thus the Brady Law regulates handgun (but not long gun) sales by licensed dealers (but not other sellers), requiring that there be an opportunity for checking the buyer's criminal record prior to transfer. Can such discriminations be passed through to the informal market, in the same manner that a tax on new guns can be passed through to the secondary market?

Our answer is "Yes, under some circumstances." The ban on transactions in certain guns may be viewed as equivalent to a prohibitive tax in the formal market. Such a ban may not eliminate the informal market for such guns-international smuggling, theft from military installations, and home manufacture may all help replenish the supply-but will at least cause an increase in price. In short, prohibited guns will sell at a premium in the informal market relative to guns that can be legally bought and sold. But whether there is an analogous premium for felons and teenagers may depend on the extent to which informal transactions are policed.

The ban on transactions to youths, felons, and certain other categories of people will discourage some from obtaining a gun and displace others into the informal market. There is little reason to expect that an informal seller will charge a higher price to a minor or a felon than to a legitimate purchaser, unless the seller faces the threat of legal penalties. So if the formal market's legal discrimination among different types of buyers is to be sustained in the informal market, informal sellers must receive a possibility of prosecution or law suit.

Finally, it is interesting to consider the matter of a mandated waiting period, which among other things provides a "cooling off" period for unarmed people with an urge to kill themselves or someone else. Faced with a wait of several days or weeks in the formal market, some people with an urgent interest in obtaining a gun will turn to the informal market. Whether or not that market will serve their needs for a quick transaction depends on a number of factors: certainly the personal connections of the buyer, but also the openness with 
which the informal market functions. Such mechanisms as gun shows and classified advertising facilitate connections in the informal market, ${ }^{102}$ undercutting the waiting-period requirement.

The previous discussion is summarized in Table 2.

\section{TABLE 2}

PASS-THROUGH OF ForMAL-MARKET RESTRICTIONS TO THE INFORMAL MARKET

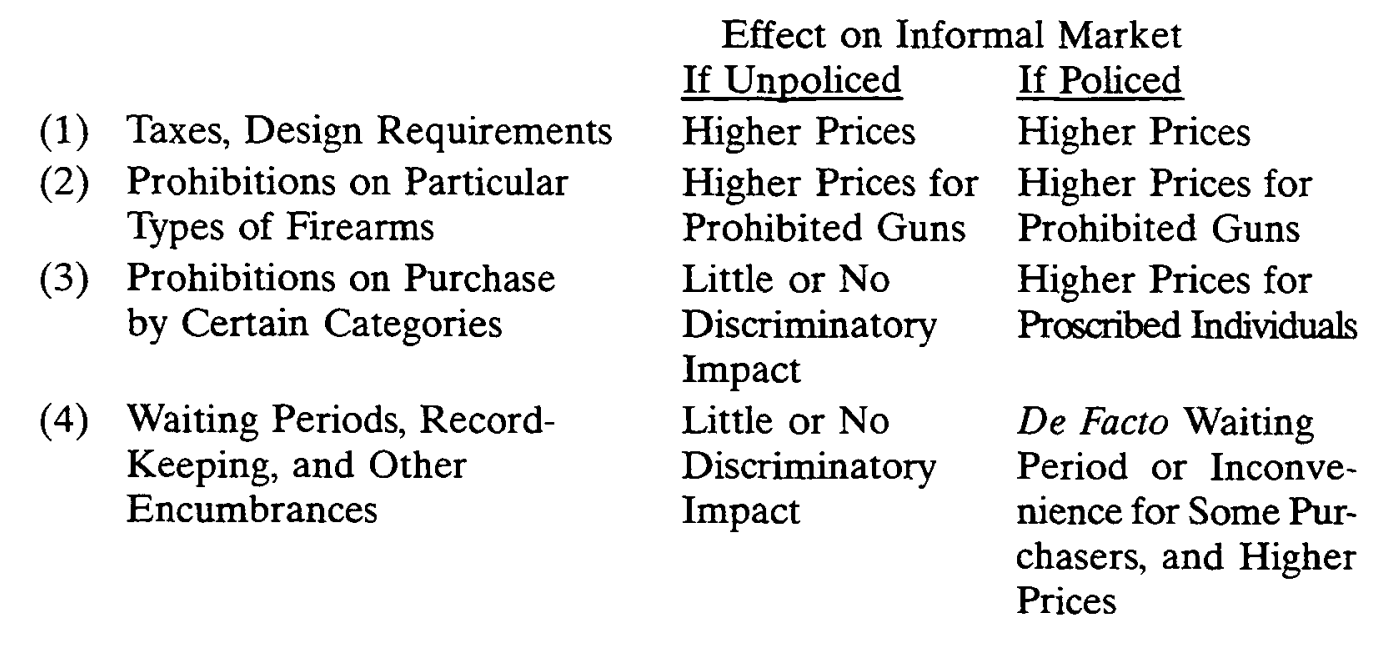

VI

SHRINKING THE INFORMAL MARKET

The above analysis suggests that informal markets mitigate the force of regulation on gun transactions but not to the point of "futility." Achieving stronger and more precisely targeted regulatory effects requires plugging loopholes or devoting more resources to policing against illegal transactions.

\section{A. Formalizing Legal Transactions}

Regulation of retail firearms transactions is for the most part limited to sales by FFLs. Anyone seeking to buy a handgun from an FFL must submit to state and federal requirements, which may include paying a fee for a permit, and everywhere includes submitting to a criminal-record check and allowing the dealer to keep a permanent record of the transaction. ${ }^{103}$ Under federal law, and most state laws as well, none of these requirements applies to purchase from a non-dealer. ${ }^{104}$ The distinction between dealers and non-dealers is somewhat curious. Imagine, for example, an automobile regulatory regime that would require purchasers of automobiles from dealers to register their vehicles

102. Cook et al., supra note 59 , at $88-89$.

103. 18 U.S.C. $\$ 922$ (1994).

104. Id.; NRA Home Page, supra note 16 (surveying state gun control laws). 
and provide proof of insurance, while waiving those requirements if the car were purchased from an individual.

A number of commentators on gun control have proposed an end to this distinction, suggesting that gun transactions be subject to the same requirements regardless of whether the seller is licensed. ${ }^{105}$ Extension of the regulatory regime would shift the boundary between the formal and informal market by bringing formerly legal but unregulated transactions into the formal sector: The legal and the formal markets would coincide. Thus many of the transfers that occur at gun shows, for example, would be formalized. Those informal transactions that under the current regime are carried out in contravention of the law (transfers to felons or minors, for example) would become more vulnerable to prosecution because the obvious legal defense-that the transferor did not know that the recipient was in a prohibited category-would no longer be useful. ${ }^{106}$

How could this extended system work in practice? One approach would be to require that every transfer be channelled through an FFL, who (presumably for a fee) would follow the same screening procedures and keep the same records as for a sale from his store. Voluntary compliance could be promoted by making the record owner liable for misuse of his gun by others, unless he had reported the gun stolen or could demonstrate that the gun had been transferred legally.

\section{B. Policing the Informal Market}

Whether or not sales by nonlicensed individuals are regulated, there will remain a large volume of informal transactions: mostly casual transfers between family or acquaintances, but also off-the-books sales by FFLs, thefts, and blackmarket dealing by interstate gun runners. While the bulk of these informal transactions are innocuous, the informal sector does serve as the principal source of guns for urban youths and criminals-that is, people who are for the most part prohibited from possessing guns. Policing these markets is typically a low priority for state and local law enforcement agencies. ${ }^{107}$ As a result, operationally useful information is scarce. But based on available information, there are some approaches that look promising.

It is useful to get the task clearly in mind. Stopping the flow of guns to dangerous people is complicated by the fact that there is such a large legal sector in the gun market. Guns that end up in the hands of youths or felons have somehow been diverted from this legal sector. The diversion may take place through a variety of mechanisms, including undocumented sales by

105. KLECK, supra note 81 , ch. 11; Cook et al., supra note 59, at 89-90. But see James Jacobs \& Kimberly A. Potter, Keeping Guns Out of the "Wrong" Hands: The Brady Law and the Limits of Regulation, 86 J. CRIM. L. \& CRIMINOLOGY 93 (1995).

106. 18 U.S.C. $\$ 924(a)(2)$ (1994) (providing for fine, up to 10 years imprisonment, or both for knowing sale to ineligible person).

107. Cook et al., supra note 59, at 76-78. 
scofflaw FFLs, sales by FFLs to "strawman" purchasers, and theft from homes and businesses. ${ }^{108}$ Once a gun has been diverted, it may be transferred a number of times within the illicit sector. One task, then, is to police the boundaries of the licit sector to prevent diversion. Another somewhat distinct task is to disrupt the markets in which guns are redistributed within the illicit sector.

Preventing diversion requires both regulation of FFLs and law enforcement. Scofflaw FFLs may be identified and put out of business by a combination of closer regulatory inspection and aggressive efforts by the police to identify sources of guns that are showing up on the "street." Gun running to the Northeast, where guns are relatively scarce, has been successfully attacked by BATF criminal investigations (sometimes in coordination with state and local agencies); ${ }^{109}$ more surprisingly, perhaps, is the apparent success of Virginia's "one gun a month" regulation in discouraging FFL sales to gun runners. ${ }^{110}$ To counter gun theft, it might be worth experimenting with public-information campaigns to persuade the public to store their guns safely; perhaps more promising is to deter gun theft by assigning special priority to prosecutions of defendants accused of stealing guns or to mandate stiffer penalties for thefts of guns than for thefts of other items of similar value. ${ }^{111}$ To sum up, there are a variety of possible tactics, using both regulatory and law enforcement capacities, that could plausibly reduce availability and increase prices in the illicit sector. ${ }^{12}$

To be effective, law enforcement tactics against the illicit sector must be quite different from those against, say, crack cocaine. There are no streetcorner gun dealers making frequent and potentially visible transactions. Police surveillance might be of some use at gun shows, but not for the bulk of illicit transactions. "Buy-and-bust" undercover operations are of little use when directed against sellers who are not "dealers" but rather people who occasionally have an extra gun and are looking to get rid of it; arresting such a person would have little effect on market supply.

A more promising approach requires the police to invest in their intelligence-gathering capacity, developing community informants and making a point

108. Id at 79,81

109. Mark H. Moore, Keeping Handguns from Criminal Offenders, in 455 ANNALS AM. ACAD. POL. $\&$ SOC. SCI. 92 (1981).

110. Weil \& Knox, supra note 100. Since the passage of Virginia's 1993 "one gun a month" legislation, Maryland has surpassed Virginia as the top supplier of handguns used to commit violent crimes in Washington, D.C. Jon Jeter, Maryland Tops Virginia as D.C. Gun Supplier; Crime Report Boosts Proposal to Limit Sales, WASH. POST, Jan. 28, 1996, at A1.

111. Cook et al., supra note 59 , at 86 .

112. The demand side of the informal gun market can be reduced by increased penalties or enforcement efforts aimed at those who own or carry illegally obtained firearms. A police policy of frisking suspects of minor violations has reportedly diminished the carrying of unregistered firearms in parts of New York City. Clifford Krauss, Shootings Fall as More Guns Stay at Home, N.Y. TIMES, July 30, 1995, at 29. An experiment in Kansas City with aggressive patrolling against illegal carrying proved highly successful in reducing gun crime. See LARRY SHERMAN ET AL., NAT'L INSTITUTE OF JUSTICE, THE KANSAS CITY GUN EXPERIMENT 1, 6 (1995). 
to ask gun-toting arrestees to name their sources. This sort of local intelligence may provide a basis for identifying sources (including FFLs) of diversion from the licit sector, as well as providing information on anyone who is acting as a broker within the illicit sector, and lead to effective interventions. ${ }^{113}$

The proximate objective of all these efforts would be to make guns scarcer to youths and criminals, and at the same time limit the information necessary for would-be buyers and sellers to make a connection in the illicit market. If we can force illicit dealers to be secretive and charge high prices, they will arm fewer dangerous people. Disrupting the more organized segments of this market will make guns a less liquid asset, more difficult to buy or sell. This approach seems promising but requires a substantial investment on the part of law enforcement and regulatory agencies.

\section{VII \\ JEOPARDY}

Our discussion so far indicates that some preemptive gun controls are likely to be neither futile nor perverse in their effects. There is still the question of whether their positive consequences are worth their associated costs. From the gun buyers' perspective, these costs are immediate: If, for example, they wish to buy a new handgun, they must deal with an in-state FFL, pay a fee to cover a background check, and wait several days to take possession. ${ }^{114}$ If they live in a restrictive jurisdiction, such as Washington, D.C. or Chicago, they face an outright ban. Such impositions on consumer sovereignty deserve due consideration in weighing the costs and benefits of any gun-control proposal, just as they would in evaluating a new restriction on, say, motor-vehicle sales. But many commentators assert that firearms are qualitatively different from other commodities, in that there exists a personal "right to keep and bear arms" that is guaranteed by the Constitution, for reasons that are just as important now as in the 18th Century. ${ }^{115}$ Further, so it is argued, law enforcement methods are objectionable in their intrusiveness and infringement on privacy. ${ }^{116}$ In short,

113. The sparseness and diffuseness of illicit gun markets (in comparison with illicit drug markets), not to mention the intrinsic danger of exchanging a lethal instrument to a potentially violent person, suggests that gun transactions would be hard to arrange, especially in an environment where lawenforcement efforts encouraged would-be buyers and sellers to be cautious about advertising their intentions. While there may exist highly circumscribed groups-youth gangs, for example-in which guns change hands relatively easily, an outsider may have much more difficulty in making a connection. In these circumstances, it may be particularly effective to attack organized elements of the market, which would be the most likely source for someone who was not associated with a group where gun possession was common. A drug dealer, for example, may be a known figure in the community, skilled at transacting with dangerous, unreliable people, and hence with a real advantage in serving as a broker in the gun market; just for those reasons, it is potentially useful for the criminal justice authorities to target drug dealers who buy and sell guns.

114. 18 U.S.C. \& $922(\mathrm{~s})(1)(1994)$.

115. Don B. Kates, Jr., Handgun Prohibition and the Original Meaning of the Second Amendment, $82 \mathrm{MICH}$. L. REV. 204 (1983); Glenn Harlan Reynolds, A Critical Guide to the Second Amendment, 62(3) TENN. L. REV. 461 (1995).

116. See, e.g., Polsby, supra note 4 , at 58. 
as Hirschman would predict, gun-control measures are said to be objectionable because they jeopardize fundamental values. ${ }^{117}$

To date the federal courts have not struck down any gun-control measure as a violation of the Second Amendment. ${ }^{18}$ The burgeoning scholarship in this area provides a great deal of information on the true meaning and intent of this Amendment, with some commentators concluding that there is a personal right to gun ownership that should be asserted by the courts. ${ }^{119}$ Even if this view ultimately triumphs, it is unclear what the effect would be, since the Court would presumably allow reasonable restrictions on the exercise of this "right." And the constitutional argument by itself is in a sense insufficient: "[M]ost people ... would not be impressed by the argument 'I admit that my behavior is very dangerous to public safety, but the Second Amendment says I have a right to do it anyway." That would be a case for repealing the Second Amendment, not respecting it. ${ }^{120}$

"Jeopardy" arguments are of the "slippery slope" variety. Whether or not the proposed gun-control measure is worthwhile in itself, it may pave the way for further restrictions or objectionable enforcement practices. If we prohibit carrying concealed weapons, then the police will be encouraged to employ illegal stop-and-frisk methods to confiscate those weapons. If we require gun owners to register their guns, some future tyrant will find it easier to confiscate them. ${ }^{121}$ If we ban armor-piercing "cop killer" bullets or plastic guns invisible to metal detectors, it is a mere prelude to much broader bans. ${ }^{122}$ Such

117. See generally HIRSCHMAN, supra note 1, at 81-132.

118. ROBERT SPITZER, THE POLITICS OF GUN CONTROL 42 (1995).

119. See, e.g., William W. Van Alstyne, The Second Amendment and the Personal Right to Arms, 43 DUKE L.J. 1236 (1994).

120. Polsby, supra note 4, at 59. Snyder, supra note 53, at 55, goes further, arguing (based on United States v. Cruikshank (1876)) that even if the Second Amendment were repealed, the right to private ownership of firearms could not be rescinded by a legitimate government: "The repeal of the Second Amendment would no more render the outlawing of firearms legitimate than the repeal of the due process clause of the Fifth Amendment would authorize the government to imprison and kill people at will."

121. Fred Kavey writes in Guns \& Ammo that requiring his people to register their firearms, and then confiscating those weapons, was one method President Marcos of the Philippines used to establish himself as "one of the world's most durable dictators." Kavey wams that such a dictator could come to power in America, and that,

if, in such a situation, the people of America still enjoy their rights as guaranteed by the Second Amendment, such a dictator's fate would be sealed. No standing army of such a despot could ever hope to defeat 100 to 200 million armed and angry Americans. But, if we should ever allow the radical, left-wing element in our country the advantages of first disarming us ... well, let's not try to think about that. It can get rather depressing.

Fred Kavey, It Can Happen in America; Right to Bear Arms by Citizens to Defend Way of Life, GuNs \& AMMO, Aug. 1985, at 31.

NRA Executive Vice-President Wayne LaPierre claims, "In Germany, firearm registration helped lead to the holocaust .... The German police state tactics led its citizens, especially Jews, defenseless against tyranny and the wanton slaughter of a whole segment of its population." LAPIERRE, supra note 5 , at 86-87.

122. James Bovard writes, "Once an assault weapons law is on the books, there is little to prevent politicians from vastly increasing the number of weapons banned under the law." James Bovard, The Assault on Assault Weapons, WALL ST. J., Jan. 6, 1994, at 12. 
arguments are not about the costs and benefits of the proposed regulation, but rather about governance, about gaining and using power. ${ }^{123}$ The rules of engagement for such arguments are not clear.

In any event, the threat to fundamental values in this arena comes not only from the overreach of government, but also from its failure to act. If dangerous people are allowed ready access to firearms, then the lives and well-being of the community are imperiled. And if heavily armed people organize around a political agenda, the result-as formerly in Medellín ${ }^{124}$ and now in many small towns in the West ${ }^{125}$ - can result in a violent challenge to legitimately chosen civil government.

\section{VIII}

\section{CONCLUSION}

A large majority of the American public favors moderate government regulation of firearms to discourage criminal use without placing excessive burdens on legitimate uses. ${ }^{126}$ Existing laws governing firearms commerce, possession, and use are generally responsive to this view. While the specifics are certainly debatable, most, but not all, people reject laissez faire as a guiding principle for such a dangerous commodity. Increasingly, not just in radical fringe groups but in academic circles and mainstream magazines of opinion, we are told that laissez faire is precisely the right policy. ${ }^{127}$ The gun advocates' arguments fit the template described by Albert O. Hirschman of "futility, perversity, and jeopardy." But the case for an unregulated gun market does not stand up well to economic logic.

First, contrary to a standard contention, the criminal justice system does not offer a satisfactory solution to the violent-crime problem. In the vast heterogeneous array of circumstances in which guns are used to harm an innocent party,

123. Such reasoning was employed by former NRA President Thomas $L$. Washington when he wrote,

To some of you, this or that [gun control] law, by itself, might not look so bad. But look at the overall trend. In the context of 200 years of U.S. history, look at what's happened to our liberties in just the last few years.... If you mathematically graphed the anti-gun trend over the past few decades, you'd see the Clinton years represent an exponentially accelerating increase, a curve that climbs at a steeper and steeper rate every year. If that trend continues through the roof, your rights will go out the window.

Thomas L. Washington, The President's Column, AM. RIFleman, Nov. 1995, at 34.

124. By the end of 1990 , at least 550 members of Colombia's political establishment had been killed as part of a terrorist revolt by leaders of the Medellin cocaine cartel. DRUG POLICY IN THE AMERICAS 1 (Peter H. Smith ed., 1992).

125. Stephen Braun, Their Own Kind of Justice: The Common Law movement's rogue courts let those alienated by America's legal system play judge and jury for a night. Radical members use the session to torment the government, L.A. TIMES, Sept. 5, 1995, at A1.

126. Tom Smith, The 75\% Solution: An Analysis of the Structure of Attitudes on Gun Control, 1959 . 1977, 71(3) J. CRIM. L. \& CRIMINOLOGY 300 (1980). Polls show high levels of public approval for moderate government regulation of manufacture, sale, possession, and carrying of firearms. Jon $\mathrm{S}$. Vernick et al., Public Opinion Polling on Gun Policy, 12 HEALTH AfF. 198 (Winter 1993).

127. Snyder, supra note 53, at 52-55; George Will, Are We a Nation of Cowards?, NEWSWEEK, Nov. 15, 1993, at 94. 
an unknown but substantial portion are beyond the reach of the criminal justice system. So a preventive strategy that incorporates gun regulation cannot be ruled out simply by calling for a crackdown on crime.

Second, the assertion that all gun controls are futile-or, worse actually perverse in their effects-is not persuasive. While highly motivated people can find their way around almost any regulatory barrier in obtaining a gun, that truism fails to demonstrate that regulations are futile. Our analysis suggests that moderate controls will reduce the availability of firearms, even to criminals and youths who traffic only in the illicit market, and will likely result in lower social costs from firearm violence.

Finally, even if the Second Amendment establishes a personal right to keep and bear arms, that right is not absolute: For instance, it clearly does not mean that children should be allowed to carry machine guns to school. There remains the necessity of sorting through the costs and benefits to society of proposed regulations, noting that infringement of privacy and individual freedom is a cost that must indeed be given its proper due. 